\title{
PERFORMANCE ASSESSMENT OF INFILLED RC STRUCTURES CONSIDERING THE INFILL MASONRY WALLS OUT-OF-PLANE BEHAVIOUR
}

\author{
André Furtado $^{1 \mathrm{~A}}$, Hugo Rodrigues ${ }^{2}$, António Arêde ${ }^{1 \mathrm{~B}}$, Humberto Varum $^{1 \mathrm{C}}$, Pedro Del- \\ $\operatorname{gado}^{3}$ \\ ${ }^{1}$ CONSTRUCT, Faculty of Engineering of University of Porto \\ Porto, Portugal \\ e-mail: A: afurtado@fe.up.pt; B: aarede@fe.up.pt; C: hvarum@fe.up.pt; \\ ${ }^{2}$ RISCO, School of Technology and Management, Polytechnic Institute of Leiria \\ Leiria, Portugal \\ e-mail: hugo.f.rodrigues@ipleiria.pt \\ ${ }^{3}$ CONSTRUCT, Superior School of Technology and Management of Polytechnic Institute of Viana \\ do Castelo \\ Viana do Castelo, Portugal \\ e-mail: pdelgado@estg.ipvc.pt
}

Keywords: Masonry infill walls, Out-of-plane, experimental testing, numerical modelling, performance assessment

\begin{abstract}
The out-of-plane (OOP) performance of infill masonry walls subjected to earthquakes is a topic of growing importance due to the significant number of collapses observed through the recent earthquakes. Nowadays is recognized by the scientific community the influence of these elements in the structural response of reinforced concrete structures subjected to seismic actions. The infills OOP behaviour depends on a series of variables and there is a lack of experimental data to understand and predict their expected seismic performance. There is a need of data to calibrate numerical models and to understand the effect of each variable such as type of masonry, boarder constrains, previous in-plane damage and insufficient support width in the infills OOP capacity. The present manuscript pretends to overview some considerations regarding the performance assessment of infills OOP performance such as based on experimental tests and numerical modeling results. A brief revision of the literature and of the international codes will be presented along the manuscript regarding this topic and will help to understand the importance of the infills OOP behaviour on the performance assessment of reinforced concrete structures.
\end{abstract}




\section{LESSONS LEARNED FROM THE PAST EARTHQUAKES ON THE IM WALLS SEISMIC PERFORMANCE}

\subsection{L'Aquila (Italy) earthquake, 2009}

The 2009 L'Aquila earthquake occurred in the region of Abruzzo, in central Italy. The main shock occurred on 6 April 2009, and was rated 5.8 or 5.9 on the Richter magnitude scale and 6.3 on the moment magnitude scale; its epicentre was near L'Aquila, the capital of Abruzzo, which together with surrounding villages suffered most damage. There have been several thousand foreshocks and aftershocks since December 2008, more than thirty of which had a Richter magnitude greater than 3.5.

Non-structural elements, in general, are very vulnerable to earthquake action namely because of the lack of earthquake design and construction detailing of non-structural elements [1]. As a result, even light to moderate earthquake shaking/acceleration or drift levels can cause damage to non-structural elements and this damage may result in life safety hazards, immediate evacuation and loss of function of buildings, limiting the use of internal spaces. Based on post-seismic damage assessment information, some examples, representative of systematic masonry enclosure wall failures, are reported and discussed. The damage suffered by masonry enclosure and infill walls by the Abruzzo earthquake in Italy, that occurred on the 6th of April 2009, particularly in the city of Aquila, is especially reported due to its representative characteristics of the Mediterranean construction. A widespread of non-structural damage, mainly the out-of-plane collapse (of the outer leaf of cavity walls); in-plane mechanisms and mixed mechanism were observed. The Abruzzo earthquake hit several villages with different intensities; the maximum acceleration registered was $0.675 \mathrm{~g}$, widely exceeding the $0.25 \mathrm{~g}$ defined in the design code. Within the reconnaissance mission of the authors, it was observed a group of systematic problems, consequence of bad construction practice.
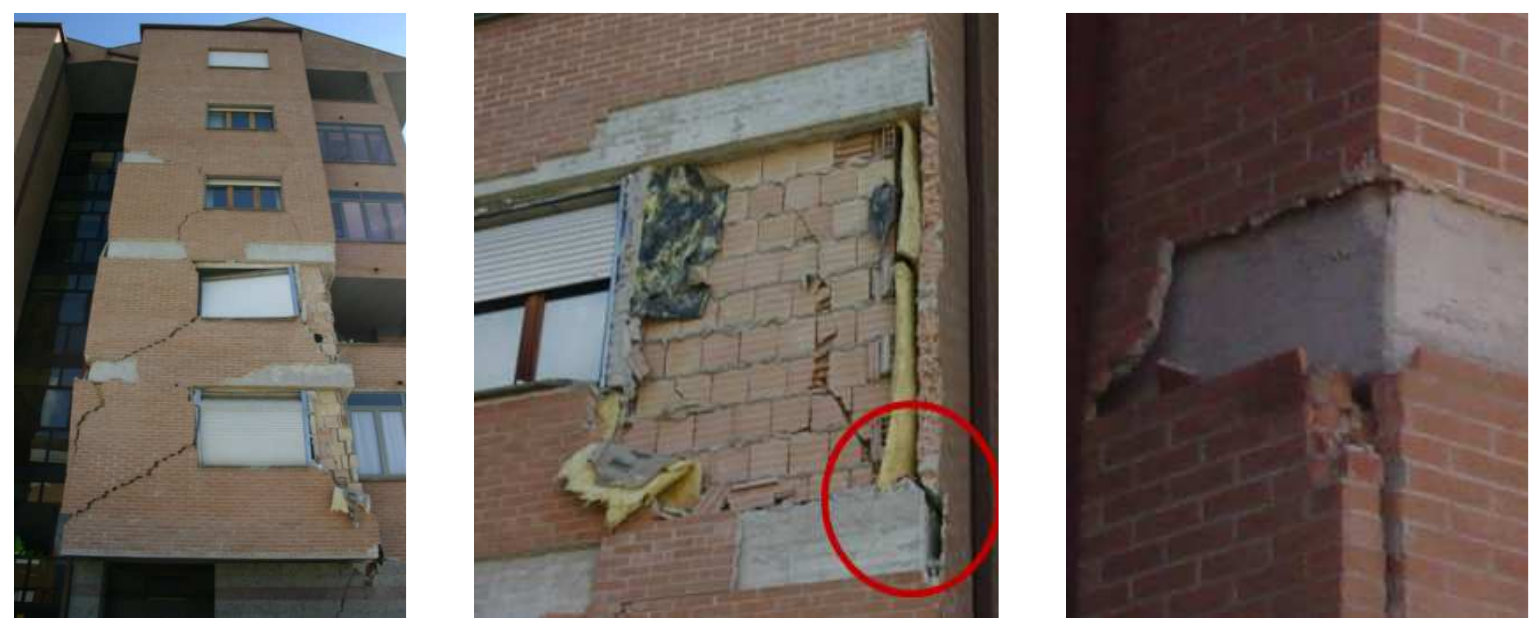

Figure 1: Cracking and collapse of the outer leaf of a double leaf wall.

The out-of-plane failure mechanisms and associated cracking patterns are influenced by several aspects, but more potentially by: i) the connection efficiency to orthogonal walls and inner leaf panels; ii) the connection efficiency to upper and lower RC beams, as well as columns; iii) the wall support conditions over concrete slab or beam. Focusing on external masonry enclosure walls, Figure 1 shows non-structural damage of masonry enclosure walls of a six storey concrete framed building after the earthquake. Possible causes that lead to this level 
of damage are related to susceptibility of the balconies to higher vertical accelerations, slenderness of the masonry leafs, unconfinement of the external leaf, and the lack of ties or anchoring systems either to the inner leaf or structural concrete frame. In Figure 1 is also evident the existence of thin brick slips with deficient adhesion to the concrete beams and insufficient width support of the outer leaf (perforated brick) over the slab/beam.

In Figure 2 is shown the extensive disconnection of the veneer wall and the its backing wall due to the lack of wall ties, lateral constraint at corner angles, and insulation fixing system to the moment frame resisting structure. In Eurocode 6 [2], section 8.5.2.2, it is recommended that the minimum number of ties, $\mathrm{n}_{\mathrm{tmin}}$, for a cavity wall or veneer wall and its backing wall should not be less than $2 / \mathrm{m}^{2}$.
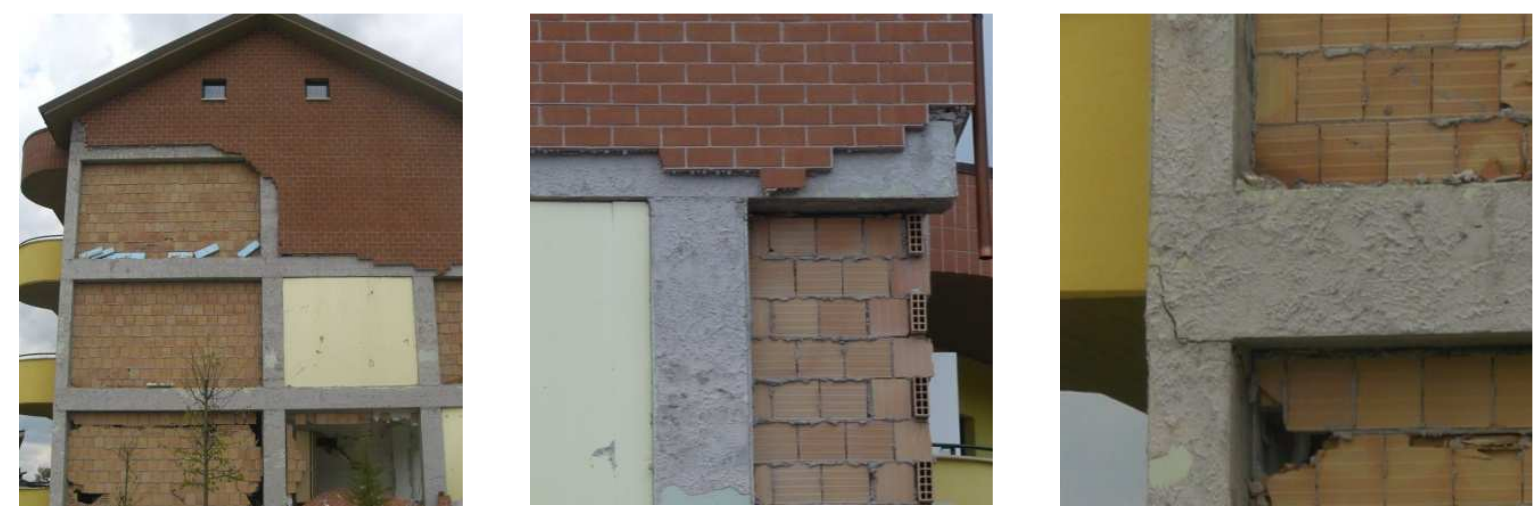

Figure 2: Total disconnection of the outer veneer cladding wall.

In both cases it is visible the inadequate mortar jointing of brick wall, being unfortunately a common practice associated to very poor workmanship. Slender walls are very sensitive to acceleration and displacement and conditioned to peripheral connection and support conditions to the concrete frame structure, as well as the connection efficiency to inner leaves and orthogonal walls. The disconnection and cracking of the exterior wall panel, is the result of the relative rotation of the wall leading to out-of-plane movement.

Due to all these aspects an out-of-plane mechanism can occur. However, this mechanism can occur for lower levels of acceleration if previous in-plane damage is inflicted over the wall.

In moderate seismic regions, Eurocode 8 [3], specifically in section 4.3.5, referring to nonstructural elements, obliges to verify the effects of seismic action over these components, as well as their connections and attachments to the main concrete frame. In the case of masonry infills, if connected, they contribute to the resistant structural system and should respect the compliance criteria specified for confined masonry. Particular attention should be paid to masonry panels with a high slenderness ratio, as will be discussed in section 4.2.

\subsection{Lorca (Spain) earthquake, 2011}

On 11 May 2011, an earthquake of magnitude $\mathrm{M}_{\mathrm{w}}=5.1$ hit the city of Lorca in the southeast region of Murcia, Spain. In many cases, the influence of non-structural infill panels showed to be the cause of severe damages in buildings. Three damage mechanisms were observed in the majority of the analysed cases. The first is associated with cases where masonry walls do not extend towards all the inter-storey height for openings, leaving a short portion of the columns clear, creating a short-column mechanism (see Figure $3 \mathrm{a}, 3 \mathrm{~b}$ and $3 \mathrm{c}$ ). The second is associated also with the short-column mechanism, but induced by the stair-slabs connected to the column (see Figure 3d). In both mechanisms, the non-consideration of the non-structural infill panels, or of the secondary elements (as the staircases) in the design, may not represent the real be- 
haviour of the columns, underestimating the column stiffness and, consequently, of the forces attracted, leading to unexpected shear failure [4].

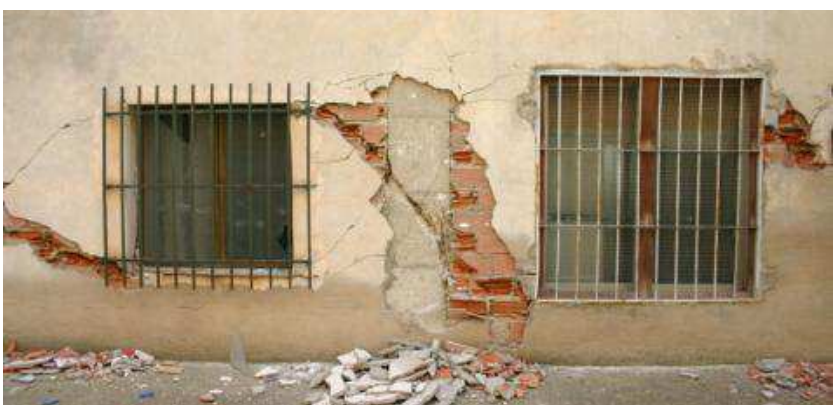

a)

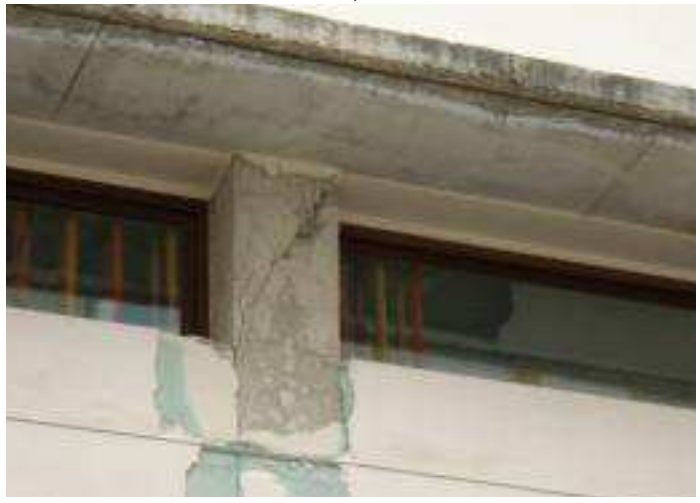

c)

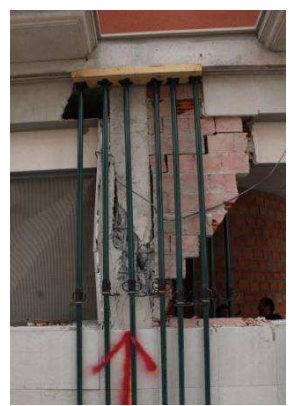

b)

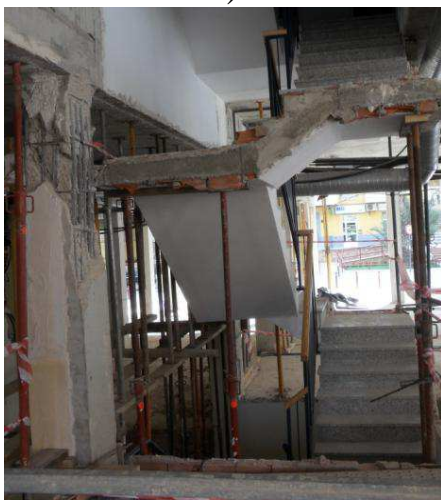

d)

Figure 3: Short-column mechanism.

Figure 4 shows the diagonal strut formed in the infill panel, evidencing the important contribution of the infill masonry panels to the global response of RC buildings. In fact, the contribution of the infill masonry panels to the global response of buildings may induces a significant increase of the storey stiffness that, if not considered in the design phase, may bring higher shear forces to the columns, leading to shear failure as observed in many cases analysed in Lorca.

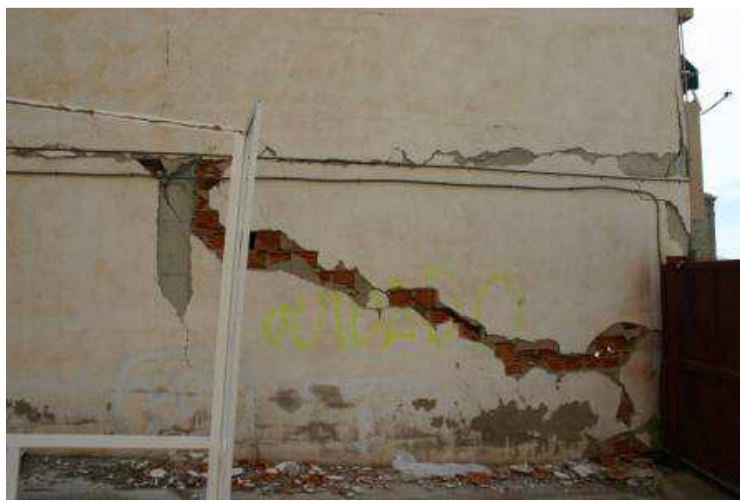

Figure 4: Diagonal strut of infill masonry panel.
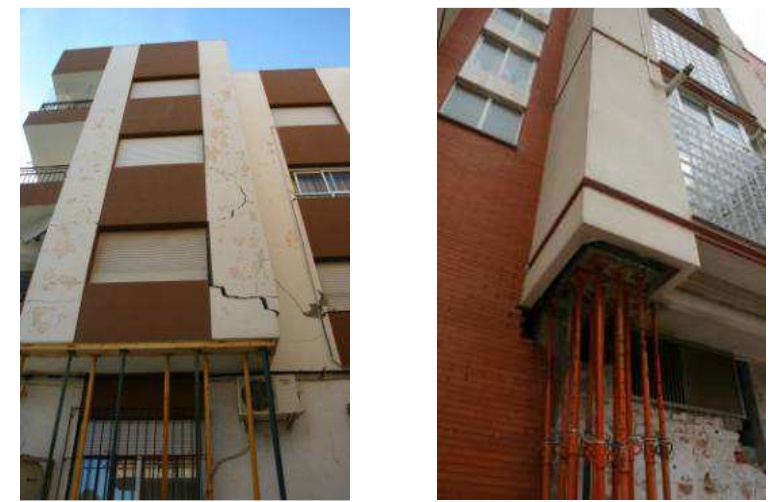

Figure 5: Balconies (vertical component effect).

\subsection{Gorkha (Nepal) earthquake, 2015}

On April $25^{\text {th }}, 2015$ a devastating earthquake of magnitude 7.8 struck Nepal, causing about 9,000 deaths and nearly 23,000 injured. The epicentre was located in Lamjung, Ghorkha district, $75 \mathrm{~km}$ northwest of Kathmandu with a focal depth of $8.2 \mathrm{~km}$. The construction of RC 
buildings has accelerated in the last 15 to 20 years, in a country dominated by masonry buildings. This constructive typology takes advantage of the combination of the mechanical behaviour of concrete and steel. In Nepal, RC frames are the prevalent type of structural load bearing system. $\mathrm{RC}$ moment frames structures are formed by a set of frames that group beams and columns. The frames are connected through slabs that allow the transfer of own weight, the inherent live loads, and other loadings to the foundations and soil. The seismic vulnerability of a typical RC building buildings is smaller compared to the typical masonry buildings. The RC frame buildings are infilled with masonry bricks which are used as partition elements and provide for the building envelope. It is worth noting that in Nepal, the infill is typically constructed using solid bricks, which introduce a unique behaviour to the infill walls when compared to hollow bricks used in some countries of Europe [5].

The RC buildings construction in Nepal presents several weaknesses on the quality control of materials (improper vibration of concrete, improper size of the aggregates and steel bars with insufficient ductility) and reduced construction quality (reinforcement detailing and provisions, and insufficient percentage of reinforcement), which have a direct impact on the bearing capacity as well as the deformation capacity of the structural elements. Another influential factor in the vulnerability was verified to be linked with the decreasing number of masonry walls on the ground floor, leading to the formation of soft-storey mechanisms, and subsequent partial/total collapse of some buildings, as illustrated in Figure 6 [6].

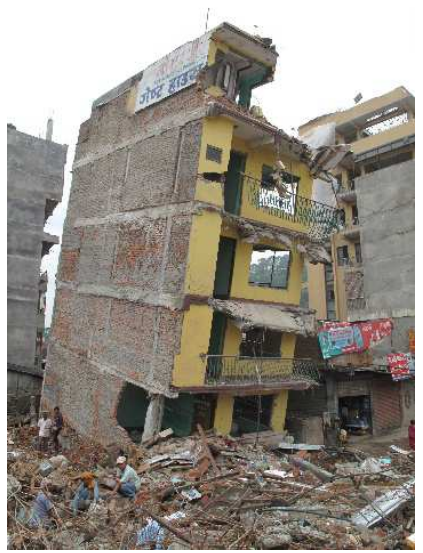

a)

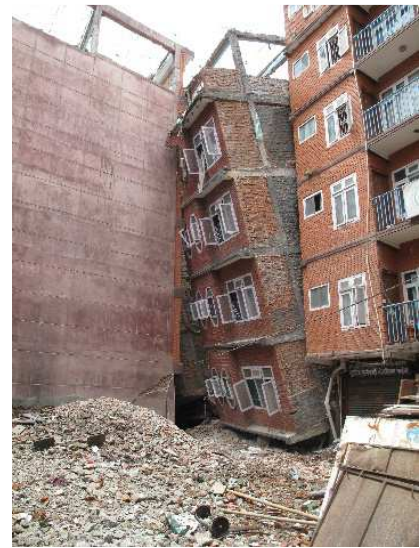

b)

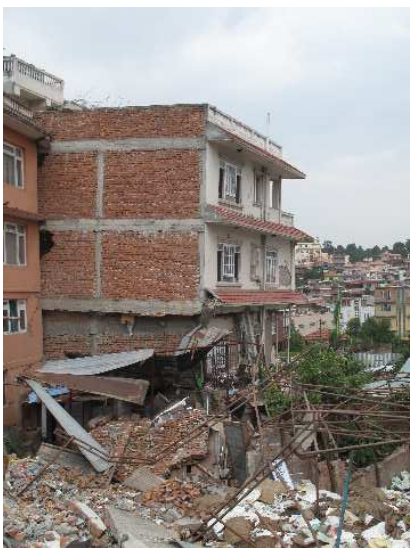

c)

Figure 6: Examples of buildings that developed a soft-storey mechanism: a) Collapse at the ground floor level, b) Collapse at ground floor and pounding an adjacent building, and c) Collapse at the 2nd storey.

For this typology, the main observations from the reconnaissance effort are: (1) In what concerns structural damages, the engineered structures (designed by NBC105 or Indian standards $[7,8]$ ) and pre-engineered buildings (MRT) behaved substantially better compared with the ones which did not follow the referred norms or due to human error; (2) There were considerable site-effects at some locations due to large soil amplifications, which resulted in several areas having a large number of buildings suffering complete collapse of the majority of buildings; (3) Regarding the non-structural damages of masonry infill panels, the majority of those were verified as combined shear-cracking and sliding at mid panel height (Figure 7a), detachment between wall and surrounding RC elements (Figure 7b), and diagonal cracking (Figure 7c). Given the characteristics of these non-structural elements (high stiffness provided by the interlock of double-leaf walls made of solid bricks), a reduced number of out-of-plane failures were observed, occurring mainly in the case non-confined walls. 


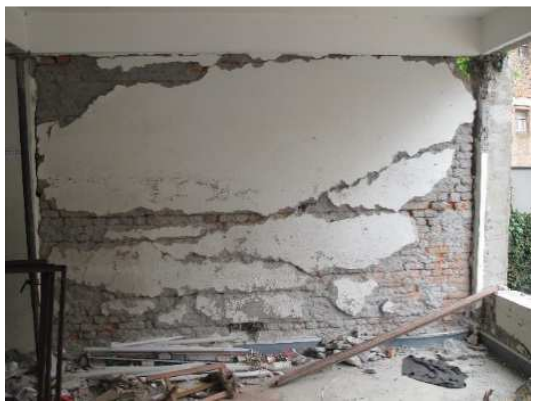

a)

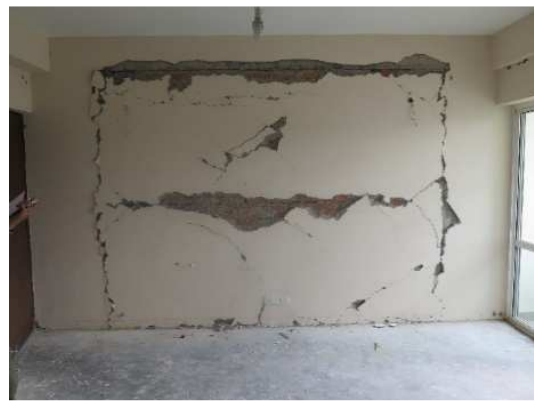

b)

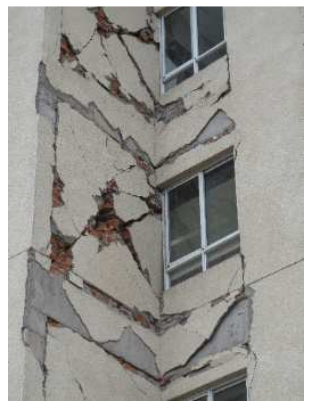

c)

Figure 7: Examples of damage in masonry infill walls: a) horizontal sliding cracks at mid height, b) Detachment of the wall from the surrounding RC elements, and c) Diagonal cracking.

In taller RC buildings with 10-18 storeys, filled entirely with infill masonry walls over the height of the structures, damages to the infill walls were also observed. However, in most cases, little to no damage occurred on the structural elements. The reduced level of damage suits the proper seismic behaviour of these structures, which were designed by the Indian National rules and standards. Even though, in many cases, damage was limited to the infill panels, it is worth noting that in many of these structures the occupants had to be moved for temporary sheltering (in some expected to more than a year) due to life-safety issues related to possible failure of the panels and until all repairs are complete.

\section{EXPERIMENTAL CHARACTERIZATION OF THE OUT-OF-PLANE CAPACITY OF IM WALLS WITH AND WITHOUT PREVIOUS IN-PLANE DAMAGE}

\subsection{Introduction}

The experimental campaign presented along the present section is composed by five out-ofplane tests of full-scale infilled RC frames with two main variables: different width support conditions of the panel, axial load on the RC columns application and previous in-plane damage. The outline of the experimental work performed is presented in this section and start firstly by the description of the out-of-plane setup developed in the LESE laboratory followed by the description of specimens tested, instrumentation and loading protocol. Finally the results of the mechanical characterization of the masonry wallets are presented.

\subsection{Test setup}

The experimental test setup was developed in order to apply a uniform distributed load through nylon airbags which main advantage is to mobilize all the infill panel considering all the distributed inertia forces that results of a seismic excitation. This test setup also allows to monitoring all the loadings involved along the test and also includes the possibility of apply axial load in the top of the infilled RC frame columns. The main innovation of this test setup resides in the fact that is the reaction structure is a self-equilibrated system that uses the RC frame stiffness and strength to react the forces developed along the test. This out-of-plane tests platform is adaptable to full-scale specimens with different dimensions, different types of masonry materials and existence of openings.

The uniform load applied through all the infill panel is reacted against a self-equilibrated steel structure composed by five vertical and four horizontal alignments that are rigidly connected to the RC frame with steel re-bars in twelve previous drilled holes (Figure 8). Between the self-equilibrated steel structure and the RC frame and linked to the steel re-bars it was imple- 
mented twelve load cells that allow to measure the forces transmitted along the experimental test. In front of the self-equilibrated steel structure it was placed a wooden platform to resist the airbags pressure and transfer it to the structure and to the tested panel.

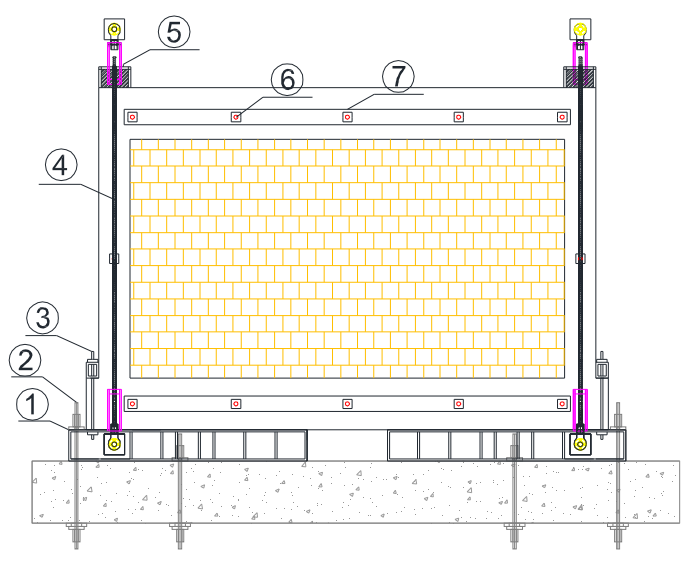

a)

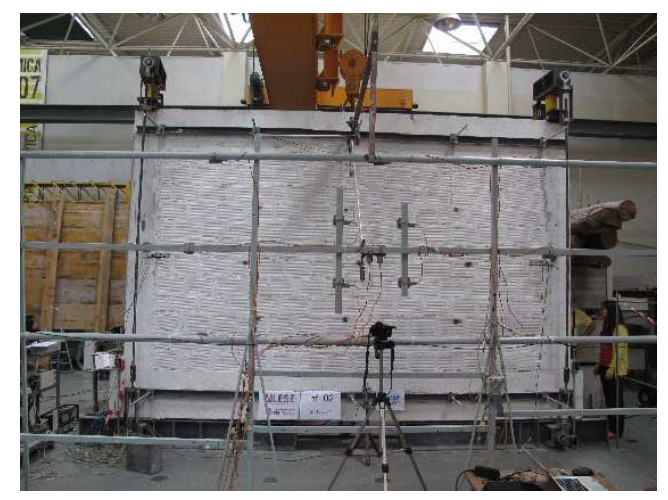

b)

Figure 8: Out-of-plane test platform developed in LESE laboratory, a) front view schematic layout, b) general front view: 0 - strong floor, 1 - foundation steel shape, 2 - high-strength rods $(\varnothing 30 \mathrm{~mm})$ fixing the foundation steel shape to the reaction slab, 3 - steel rod $(\varnothing 20 \mathrm{~mm})$ connecting the RC frame to the foundation steel shape, $4-$ vertical high-strength rods $(\varnothing 30 \mathrm{~mm})$ to apply axial load, 5 -steel cap, 6 - steel rods $(\varnothing 20 \mathrm{~mm})$ connecting the RC frame and the reaction structure, 7 - distributing load plate.

In each column the axial load was applied by means of a hydraulic jack inserted between a steel cap placed on the top of the column and an upper HEB steel shape, which, in turn, was connected to the foundation steel shape resorting to a pair of high-strength rods per column. Hinged connections were adopted between these rods and the top and foundation steel shapes; the axial load actually applied on the columns was continuously measured by load cells inserted between the jacks and the top of each columns. The pressure level inside the airbags was set by two pressure valves which were controlled according to the target and measured out-of-plane displacement of the central point of the infill panel (the control node and variable) continuously acquired during the tests using a data acquisition and control system developed in National Instruments LabVIEW software platform [9] (Figure 9).

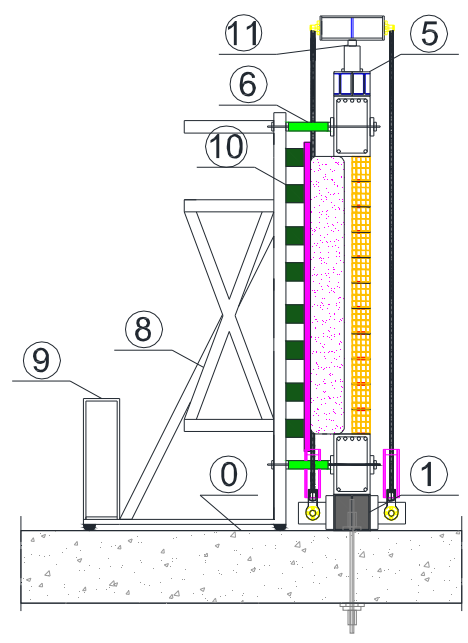

a)

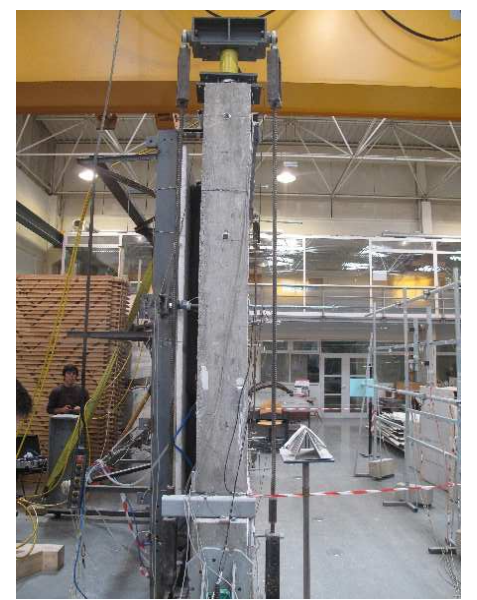

b)

Figure 9: Out-of-plane test platform developed in LESE laboratory, a) front view schematic layout, b) general front view: 0 - strong floor, 1 - foundation steel shape, 2 - high-strength rods $(\varnothing 30 \mathrm{~mm})$ fixing the foundation 
steel shape to the reaction slab, 3 - steel rod $(\varnothing 20 \mathrm{~mm})$ connecting the RC frame to the foundation steel shape, 4 vertical high-strength rods $(\varnothing 30 \mathrm{~mm})$ to apply axial load, 5 -steel cap, 6 - steel rods $(\varnothing 20 \mathrm{~mm})$ connecting the RC frame and the reaction structure, 7 - distributing load plate.

\subsection{Specimens' detailing}

The main goal of the experimental campaign was to study the out-of-plane behaviour of IM panels representative of those existing in the Portuguese building stock. For this a statistical study was conducted [10] from which was collected information concerning the structural and non-structural elements from eighty existing buildings from Portugal. The specimens' dimensions were decided according to this study and the infilled RC frame was $4.80 \mathrm{~m}$ width and $3.30 \mathrm{~m}$ height, as illustrated in Figure 10 , with the columns cross-sections $0.30 \times 0.30 \mathrm{~m}^{2}$ and the top and bottom beams $0.30 \times 0.50 \mathrm{~m}^{2}$. For the concrete it was adopted a $\mathrm{C} 20 / 25$ class and for the steel A500 class.

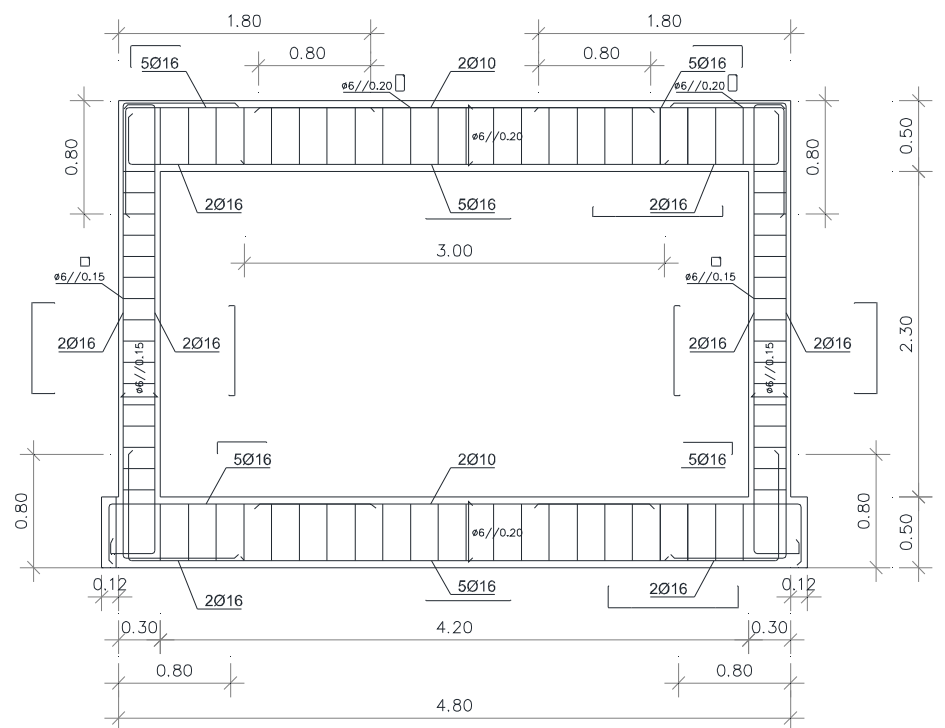

Figure 10: LESE specimens' dimensions and reinforcement detailing.

The infill panels tested were built with hollow clay horizontal bricks with the dimensions $0.30 \times 0.20 \times 0.15 \mathrm{~m}$, as frequently adopted in the Southern Europe and in particular in Portugal. Regarding the mortar it was adopted a typical M5 class ("Ciarga" type). Five specimens were built and the main considerations between the tests are described in Table 1.

\begin{tabular}{|c|c|c|c|c|c|}
\hline Specimen & $\begin{array}{l}\text { Previous in-plane drift } \\
\qquad(\%)\end{array}$ & $\begin{array}{l}\text { Axial Load } \\
\quad(\mathrm{kN})\end{array}$ & $\begin{array}{l}\text { Type of } \\
\text { test }\end{array}$ & $\begin{array}{l}\text { Panel support condi- } \\
\text { tions }\end{array}$ & $\begin{array}{l}\text { Brick unit size } \\
\quad l \times h \times t \\
(\mathrm{~mm})\end{array}$ \\
\hline Inf_01 & - & 270 & Monotonic & Full support & \multirow{5}{*}{$300 \times 200 \times 150$} \\
\hline Inf_02 & - & - & Cyclic & Full support & \\
\hline Inf_03 & $0.5 \%$ & - & Cyclic & Full support & \\
\hline Inf_04 & - & 270 & Cyclic & Full support & \\
\hline Inf_05 & - & - & Cyclic & $2 / 3$ width & \\
\hline
\end{tabular}

Table 1: Summary of the experimental tests, loading test, type of test and panel support conditions. 


\subsection{Instrumentation and test protocol}

In order to obtain the panel out-of-plane displacements and rotation between the panel and RC frame it was used twenty-one displacement transducers, thirteen of them LVDTs and the remaining eight DWTs. The LVDTs were divided along three vertical and three horizontal alignments distributed along the quarters of each dimension of the panel. The rotation of the panel was measured through a pair of DWT placed at the middle border of each side of the panel. As previously stated before, twelve load cells were used to monitoring the forces of each steel re-bar that link the RC frame and the reaction structure during the tests.

The first specimen Inf_01 and Inf_04 was subjected to a monotonic test combined with axial load of $270 \mathrm{kN}$ in the top of the columns. The panel was subjected to out-of-plane displacements until reach the collapse. Cyclic out-of-plane displacements were imposed on the remaining specimens with steadily increasing displacement levels, targeting the following nominal peak displacements: $2.5 ; 5 ; 7.5 ; 10 ; 15 ; 20 ; 25 ; 30 ; 35 ; 40 ; 45 ; 50 ; 50 ; 55 ; 60 ; 65$ and $70(\mathrm{~mm})$. Two cycles were repeated for each lateral deformation demand level at the control node chosen as the central point of the IM wall where concentrated deformation was expected.

\subsection{Material properties}

Mechanical characterization tests were performed in masonry wallets in order to obtain further information about the properties such as compressive strength, diagonal shear strength, parallel and perpendicular flexural strength and are illustrated in Table 2. Additionally, material characterization tests were conducted to the mortar and a mean compressive strength of $8.76 \mathrm{MPa}$ with coefficient of variation $(\mathrm{COV})$ of $7.33 \%$, a mean tensile strength of $5.16 \mathrm{MPa}$.

\begin{tabular}{|c|c|c|c|c|}
\hline \multirow{2}{*}{ Type of test } & \multicolumn{2}{|c|}{$\mathrm{f}_{\mathrm{m}, \mathrm{w}}$} & \multicolumn{2}{|c|}{$\mathrm{E}_{\mathrm{m}, \mathrm{w}}$} \\
\cline { 2 - 5 } & Mean $(\mathrm{MPa})$ & $\mathrm{COV}(\%)$ & Mean $(\mathrm{MPa})$ & $\mathrm{COV}(\%)$ \\
\hline $\begin{array}{c}\text { Compressive } \\
\text { strength }\end{array}$ & 1.1 & 11.3 & -941.9 & 24.8 \\
\hline Diagonal shear & 0.60 & 20.1 & - & - \\
\hline Parallel flexural & 0.11 & 43 & - & - \\
\hline $\begin{array}{c}\text { Perpendicular } \\
\text { flexural }\end{array}$ & 0.379 & 9.5 & - & - \\
\hline
\end{tabular}

Table 2: Summary of the main results of the mechanical characterization tests in IM wallets.

\subsection{Experimental results}

From the force-displacement hysteretic curves of all the tested specimens plotted in Figure 11, the following main observations can be drawn:

- The maximum strength was almost four times higher for the tests without previous inplane damage (Inf_01 and Inf_02) and for higher out-of-plane drift values. For the Inf_01 and Inf_02 tests the maximum strength occurs for out-of-plane drift values of $1.5-2 \%$;

- Through the comparison between the specimens Inf_01 and Inf_02, it can be observed that the initial stiffness of the IM walls was slightly affected by the axial loading in the RC columns. Namely, it was verified that the test with axial load (Inf_01) had about $5 \%$ more initial stiffness when compared with Inf_02;

- It was also verified that the initial cracking for the lower out-of-plane drift values for the Inf_02 was about $10 \%$. The cracking force in both experimental tests was about $50 \mathrm{kN}$. 
- The rupture of the panel Inf_04 occur for the out-of-plane displacement of $7.23 \mathrm{~mm}$ which corresponded to a maximum strength of $46 \mathrm{kN}$, which was $64 \%$ higher than the Inf_05 that reached $27.8 \mathrm{kN}$. However it was observed that the panel Inf_05 achieved the maximum out-of-plane force for a larger out-of-plane displacement than the observed for the specimen Inf_04;

- The cracking displacement of both of the panels (Inf_04 and Inf_05) was around $15 \mathrm{~mm}$. After the appearance of the first crack that corresponded to the exhaustion of the out-of-plane capacity of the wall Inf_04 the out-of-plane force reduced from 46kN until $28.3 \mathrm{kN}$. Regarding the Inf_05 it was not observed degradation of the force along the test.

- From the comparison between the specimens Inf_01 and Inf_04 it can be observed that the first obtained 50\% higher out-of-plane capacity. Besides the same axial load in the top of the columns and being subjected to different loading solicitations (monotonic and cyclic respectively) the main differences that justify the out-of-plane capacity can be associated to the mortar properties of each test;

- Regarding the tests Inf_02 and Inf_05, both tested cyclically and without axial load in the columns it can be observed that Inf_05 reached 2 times and half lower out-of-plane force than the Inf_02 justified by the support conditions of the panel. However it can be observed that the displacements where there is more strength degradation are very similar in both of the tests;

- From the tests it was observed that the Inf_01 obtained less $7.4 \%$ initial stiffness than the Inf_04 specimen, and the test Inf_02 obtained 58.6\% higher initial stiffness than Inf_05.

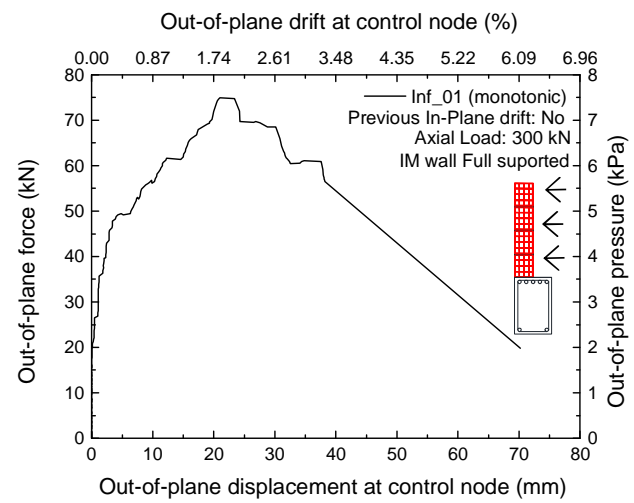

a)

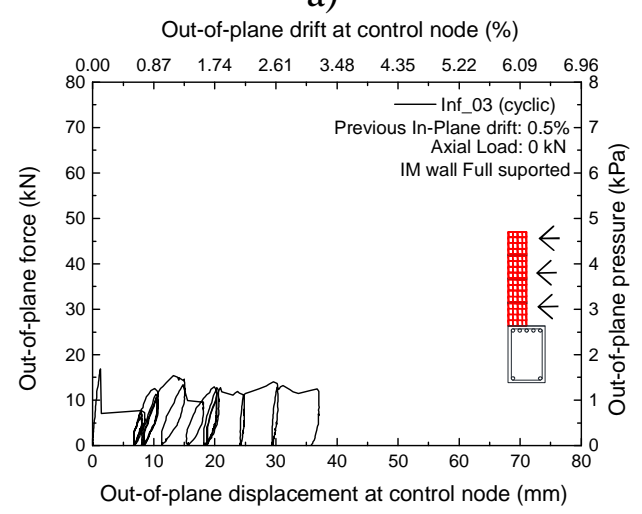

c)

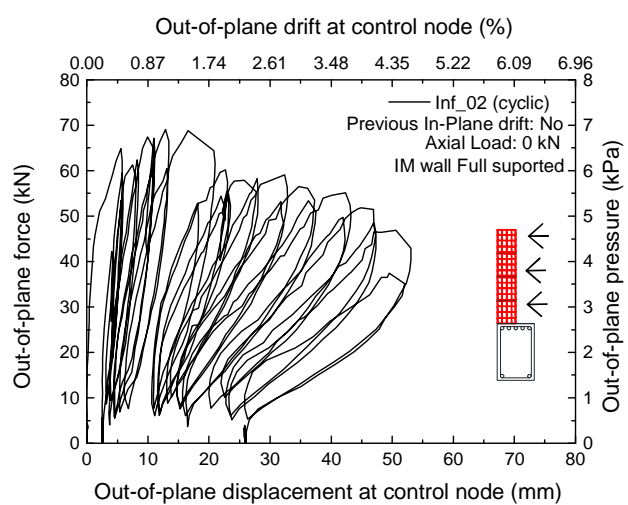

b)

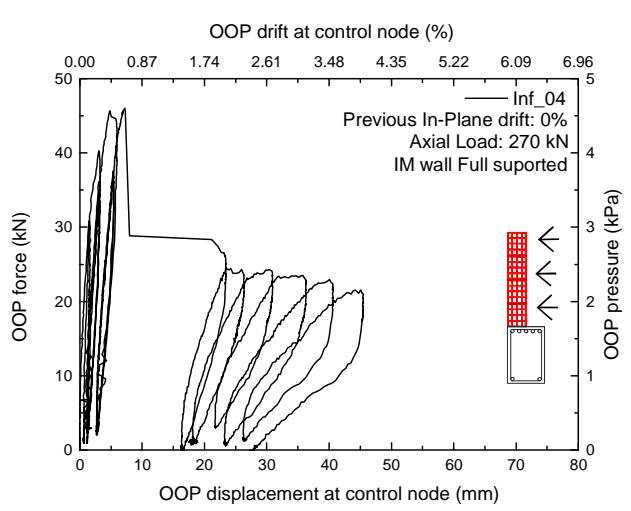

d) 


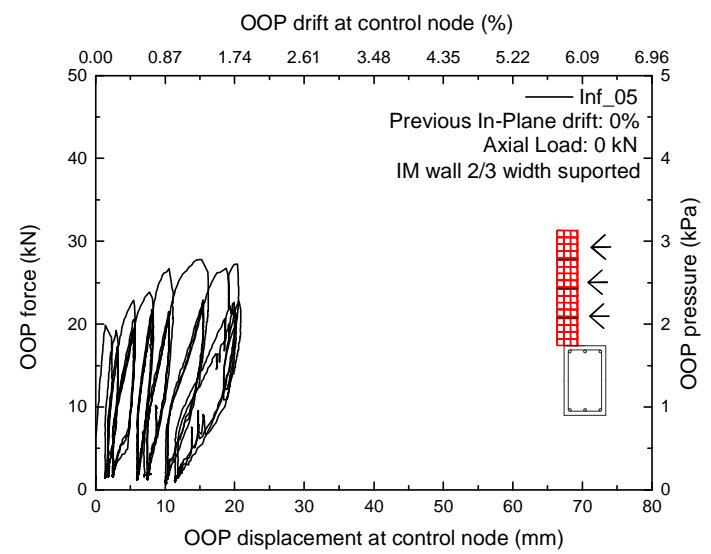

e)

Figure 11: Out-of-plane force-displacement test results: a) Inf_01; b) Inf_02; c) Inf_03; d) Inf_04 and e) Inf_05.

\section{NUMERICAL STUDY OF THE INFILL MASONRY WALLS IN-PLANE AND OUT-OF-PLANE INTERACTION}

\subsection{Description of the modelling strategy}

The IM wall simplified macro-model presented here, to be used in the software framework OpenSees [11], is based on the Rodrigues et al [12] proposal which is an improvement of the commonly used equivalent bidiagonal-strut model. Each masonry infill wall is simulated by four diagonal struts with rigid behavior, and one central element where the non-linearity hysteresis is concentrated. With the main purpose of introduce the out-of-plane behaviour of the IM wall, the panel mass is distributed by the two central nodes (Figure 12).

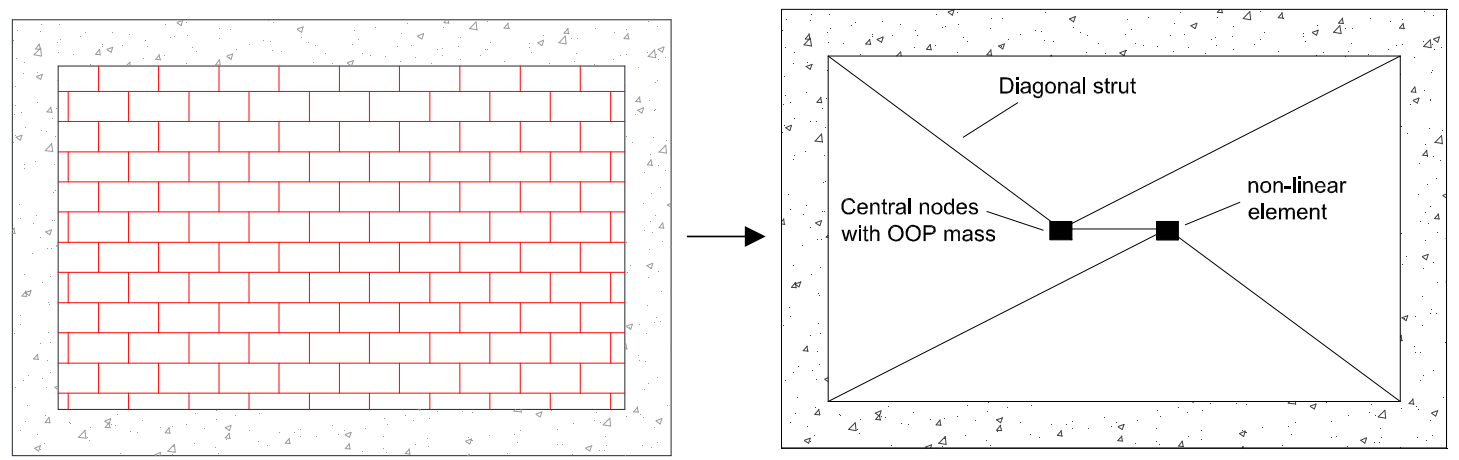

Figure 12: IM wall simplified macro-model general view.

The numerical model was designed to be composed with the available elements and materials in the OpenSees library [11]; thus, for the five linear elements the BeamWithHinges elements can be adopted or, alternatively, four elastic BeamColumns can be used for the diagonal struts and one nonlinear BeamColumn for the central element as previously studied by some of this paper authors [13].

This numerical model is designed to represent the IM wall non-linear behaviour when subjected to biaxial cyclic loading, such as in-plane and out-of-plane. These two components are defined independently although when subjected to simultaneous in-plane and out-of-plane cyclic actions they interact through an element removal algorithm that was developed by Musalam and Gunay [14]. The following sub-section describes the in-plane and out-of-plane modelling strategy. 
The consideration of the out-of-plane behaviour through simplified macro-models is difficult, for which there is not much information neither about experimental studies relative to the outof-plane behaviour of IM walls, considering all the relevant parameters, nor about the interaction between in-plane and out-of-plane response [15].

For the present simplified macro-model, the following considerations were taken into account to represent the IM walls out-of-plane behaviour:

- The out-of-plane behaviour is considered to follow a linear elastic curve;

- The numerical representation of this behaviour was implemented through the application of mass at the central nodes, which can be calculated as $0.81 \mathrm{M}(\mathrm{M}$ is the total mass of the infill panel) and equally divided per the two central nodes with $0.405 \mathrm{M}$ mass each. Assuming the model has the same natural period as the original infill wall, the OP mass and bending stiffness values were considered following the recommendations of FEMA-356 [16] and ASCE-41 [17] and the suggestions of Gunay et al [18].

- In order to obtain a realistic representation of the infill panel behavior when subjected to biaxial loadings, it was added an element removal algorithm for masonry walls developed by Musalam et al [14]. This algorithm was developed for automated removal of collapsed elements during an ongoing simulation. The IM wall is considered as collapsed when reaching the in-plane and out-of-plane interaction drift limits. Afterwards, the algorithm removes the 5 elements, the corresponding central nodes and respective masses.

The interaction between the IP and OP drift can be defined according to different dispositions, but for the present study this interaction was adopted to follow a linear pattern and the limits can be selected on the basis of previous experimental tests $[18,19]$. In the literature a much reduced number of biaxial experimental tests of IM walls can be found, for which further investigations should be performed to quantify this interaction and to better support the definition of displacement limits for the interaction law. In Figure 13 is explained the consideration of the out-of-plane behaviour in the numerical model.

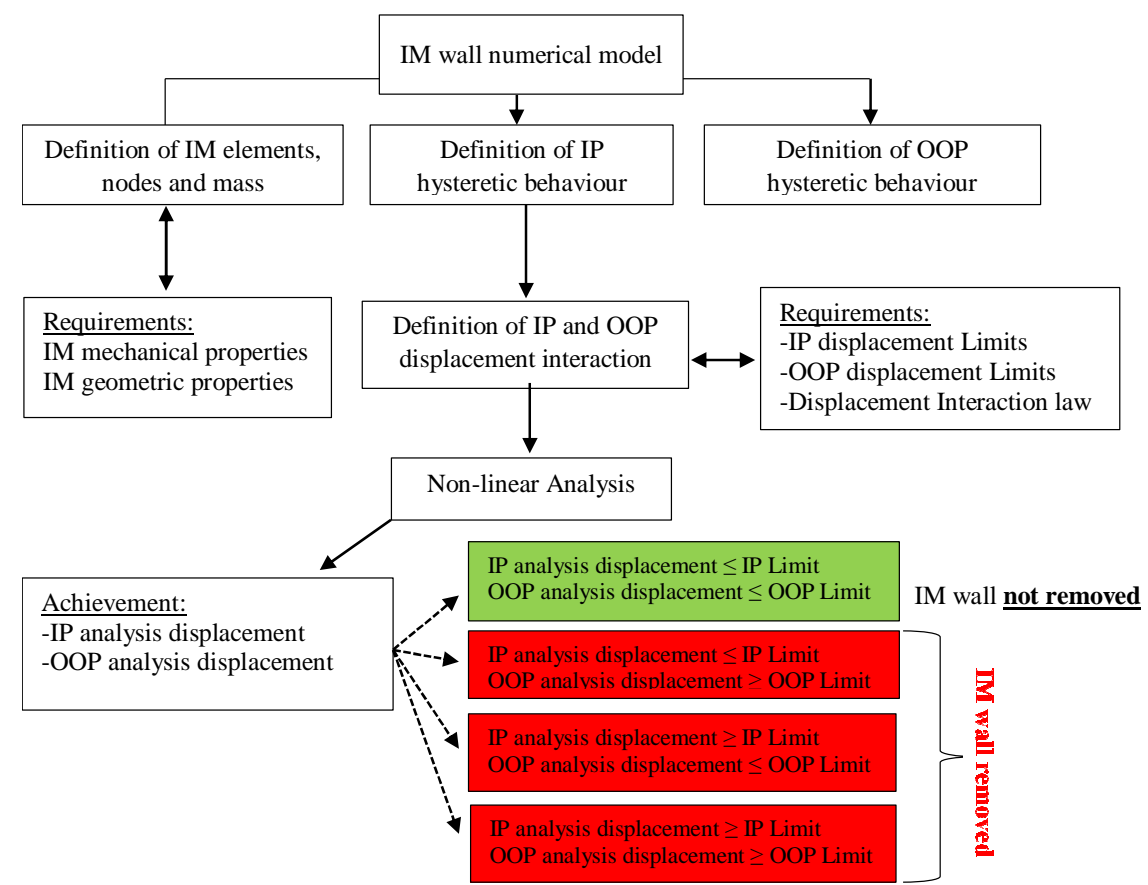

Figure 13: IM wall numerical model: consideration of the out-of-plane collapse. 


\subsection{Case study}

The influence of the IM walls, with and without the consideration of the out-of-plane behaviour in the structural response of RC buildings subjected to seismic actions, was studied taking as an example an eight storey building. The so called PT8building has in-plan dimension of $20 \times 15 \mathrm{~m}^{2}$ arranged in $4 \times 5 \mathrm{~m}^{2}$ modules, with $3 \mathrm{~m}$ storey height as shown in Figure 14. The building was designed by the Portuguese Laboratory of Earthquake and Civil Engineering - LNEC as part of a study about the seismic design of buildings, in accordance with the existing code rules in Portugal [20]. For the present study, a 3D model was generated in the computer software OpenSees [11].

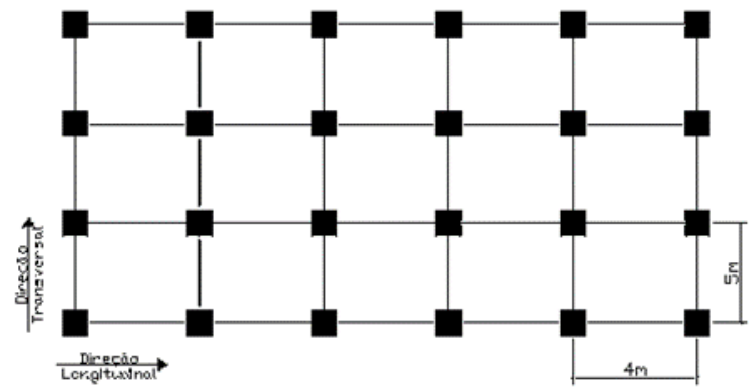

a)

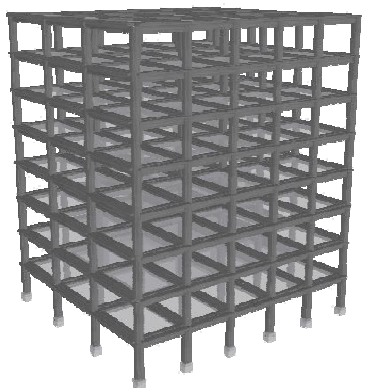

b)

Figure 14: Case study: a) In plan layout and b), 3D bare frame model.

A set of 3 building configurations was selected according to the adopted IM modelling strategies: (i) Bare Frame model (BF) which does not consider the presence of the IM walls; (ii) InPlane model (IP) in which the presence of the IM walls is considered in the external building perimeter and the only the IP behaviour is activated; (iii) Out-of-plane model (IP_OOP) which considers the presence of the IM walls in the external perimeter of the building and the in-plane and out-of-plane behaviour interaction with the element removal algorithm.

The buildings under study was subjected to non-linear dynamic time-history analysis, particularly to one artificial earthquake that was been generated for a medium/high risk scenario in southern Europe for different return periods. Hazard consistent time series of acceleration (with 90 seconds of duration) were artificially generated yielding a set of seven uniform hazard response spectra for increasing periods.

\subsection{Numerical results}

In Figure 15 it is possible to observe the differences between the drift response obtained with the three numerical models for three inter-storey zones $\left(0\right.$ to $1^{\text {st. }} ; 2^{\text {nd }}$ to $3^{\text {rd }}$ and $6^{\text {th }}$ to $7^{\text {th }}$ storeys). It can be found that:

- the inter-storey drift evolution from 0 to $1^{\text {st }}$ floor is higher for the BF model, with a maximum drift of $4.2 \%$, while only $0.7 \%$ is reached for the IP and IP_OOP model;

- The inter-storey drift between the $2^{\text {nd }}$ to $3^{\text {rd }}$ floors in the IP_OOP model is more than 4 times higher the BF and IP model, at $74.95 \mathrm{sec}$, as a consequence of the respective IM walls collapse. 


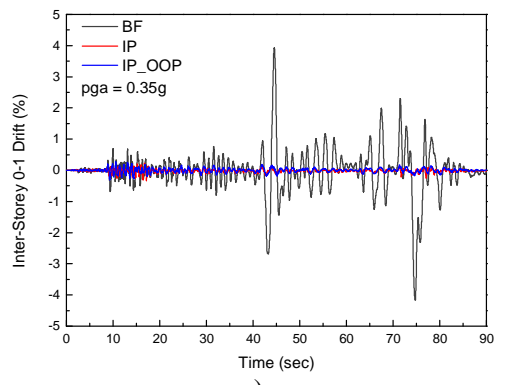

a)

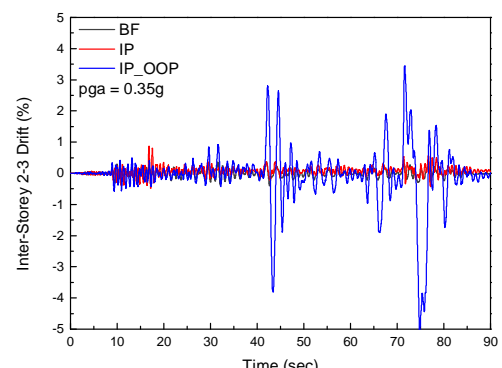

b)

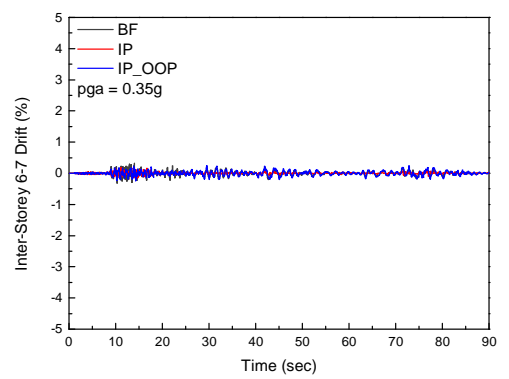

c)

Figure 15: Evolution of the inter-storey drift for: a) 0-1, b) 2-3 and c) 6-7 storeys.

Figure 16 shows plots of the maximum inter-storey drift against the peak ground acceleration. It can be observed that the BF model has larger maximum inter-storey drifts in both directions and that the transversal direction is the most vulnerable direction of the building as the maximum inter-storey drift increases sharply after $0.14 \mathrm{~g}$. A significant difference between the IP and the IP_OOP models is quite apparent, because:

- For the IP model the infills are protective for peak ground accelerations up to $0.2 \mathrm{~g}$, leading to similar response of the building in both directions for larger peak ground accelerations;

- The IP_OOP model exhibits response similar to the BF model in the longitudinal direction. In the transversal direction it can be observed that the inter-storey drift of the IP_OOP model increase significantly for peak ground accelerations upper than $0.2 \mathrm{~g}$. This is justified by the out-of-plane collapse of the $5^{\text {th }}$ storey infills' in the transversal direction occurs and, consequently, a soft-storey mechanism forms which largely increases the inter-storey drift value.
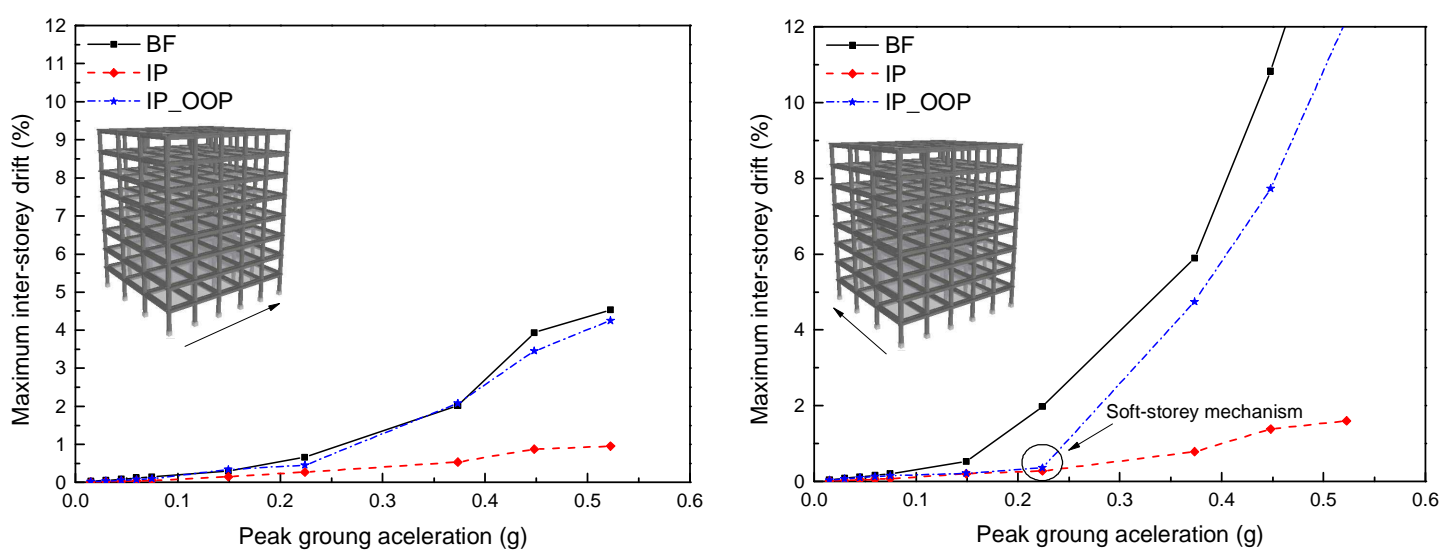

Figure 16: Evolution of the inter-storey drift for: a) 0-1, b) 2-3 and c) 6-7 storeys.

\section{CODES RECOMMENDATIONS FOR INFILLED RC STRUCTURES}

Some international codes recommends various formulations for the analysis the IM walls for both in-plane and out-of-plane directions. For instance, FEMA [21] specifies that masonry infill panels shall be represented as equivalent diagonal struts and may be placed concentrically across the diagonals, or eccentrically to directly evaluate the infill effects on the columns. It specifies strength requirements for column members adjacent to infill panels. The shear force demand may be limited by the moment capacity of the column with reduced length.

EC8 [3] specifies that the period of the structure used to evaluate base-shear stress shall be the average between periods for the bare frame and for the elastic infilled frame. Frame member actions are then determined by modelling the frame without the struts. Irregular infill ar- 
rangement (in plan and elevation) is addressed with important recommendations to avoid the formation of soft-storeys and torsion-effects. Moreover, designing techniques are suggested to account for irregularities, such as increase of accidental eccentricities use of threedimensional analysis. Regarding irregularities in elevation, if a refined model is not used, the code suggests the computation of a magnification factor to increase the seismic actions on columns (only).

Regarding the lateral load shared between infill walls and frame, EC8 [3] does not make a reference to the infill walls, considering only that the frame system should resist totally the vertical loads, and to have a $65 \%$ base-shear capacity $-50 \%$ as de minimum for other types of structure - of the total lateral loading on the building. For the serviceability limit state it is recommended the control of lateral deformation between storeys (drifts, dr). For buildings with brittle non-structural elements, it should be limited to $0: 005 \mathrm{~h}=\mu$. For buildings with ductile non-structural elements the drift is limited to $0: 0075 \mathrm{~h}=\mu$, or $0: 010 \mathrm{~h}=\mu$ if he building does not have non-structural elements. (h is the height of the storey, and $\mu$ is the reduction coefficient ranging from 0.4 to 0.5 , depending on the importance class). Due to the nature of the infill masonry walls, non-structural and brittle elements, the limit to use should be $0: 005 h=\mu$. There are some international codes that provides some recommendations on the OOP capacity of infills, as well as the indications given about the design demand acting on them. For example the Italian Building Code (NTC08) [22] gives some indications regarding OOP seismic action on infill considered as non-structural elements, but no provision aimed at determining their OOP capacity; FEMA306 [23] provides some recommendations on infills OOP strength, but no indication on their maximum displacement capacity.

Eurocode 6 [2], in section 6.3.2, proposes an expression (Equation 1) to calculate the lateral strength of masonry walls in which arching action can occur; this relationship can be extended, eventually, to infill panels:

$q=f_{d}\left(\frac{t}{l_{a}}\right)^{2}$

Equation 1

In this relationship $f_{d}$ is the design compressive strength of masonry in the direction of arching thrust while la is the panel dimension in the same direction. The maximum OOP load is the one that equilibrates the maximum thrust that can form in the masonry wall thickness determined from:

$N_{a d}=1.5 f_{d}\left(\frac{t}{10}\right)$

Equation 2

FEMA 273 [24] and FEMA 356 [16] provide some indications concerning the ultimate OOP displacement of infills with reference to different Limit States. In particular, a 2\% OOP drift is set as maximum displacement for Immediate Occupancy Limit State: this drift value corresponds with the opening of visible cracks on the panel surface; with reference to the Life Safety Limit State a 3\% OOP drift is fixed as limit displacement: this drift value corresponds with high possibility of detachment and expulsion of at least part of the infill. FEMA356 [16] sets a 5\% OOP drift as maximum displacement at Collapse Prevention. These indications are effective for both new and existing buildings.

FEMA273 [24] lists the conditions that allow considering arching action in the assessment of infills OOP strength, such as the effectiveness of the infill connection to the surrounding frame, its columns and beams stiffness and strength, and the panel slenderness. Among these statements, the one referring to the infills boundary conditions seems to be the most significant. In fact, the analysis of the experimental database presented in section 4 shows that, even 
for panels with slenderness greater than the value proposed as upper limit for the arching action effectiveness, the best strength prediction was provided by relationships based on that resistant mechanism. Under the above-mentioned conditions, it is possible to express the lateral strength of the infill as Equation 3:

$$
Q=\frac{0.7 \times f_{m} \times \lambda_{2}}{(h / t)}
$$

in which $\mathrm{f}^{\prime} \mathrm{m}$ is the lower bound of the compressive strength of masonry calculated by dividing by 1.6 (by 1.3 according to FEMA356 [16]) its average compressive strength; $\lambda_{2}$ is a slenderness parameter. FEMA274 [21] points out that the previous expression is the relationship by Angel simplified to evaluate a lower bound of the infills lateral strength. To compute it, FEMA306 [23] provide Angel's relationship without modifications. This means that FEMA306 take into account OOP strength reduction due to IP damage explicitly, even if it is not stated how to set the IP drift at which the OOP strength should be assessed.

\section{CONCLUSIONS}

This manuscript presents a research work regarding the IM walls seismic behaviour, such experimental and numerical, and their interaction with the RC structures. Their recent performances in recent earthquakes motivated the present study, in particular the evaluation of the out-of-plane capacity of the infill panels with and without considering the interaction with inplane behaviour. Thus an experimental campaign carried out at the LESE at the Faculty of Engineering of the University of Porto in order to study the out-of-plane behaviour of IM walls, and the influence of the previous in-plane drift in their out-of-plane response. For this, five full-scale infill panels were constructed and were subjected to out-of-plane monotonic and cyclic loading, with and without previous in-plane drift. The out-of-plane loading was applied by using an innovative structure that was specially constructed to undertake this type of experimental test. A significant difference was found between tests' results, with and without previous in-plane damage, namely: a) the maximum strength was almost 4 times higher for the tests without previous in-plane damage, and for higher out-of-plane drift values; b) a significant reduction of the initial stiffness was observed in the test with previous in-plane damage when compared with the other ones; c) a significant maximum strength reduction was found in the tests without the previous in-plane damage, which was not verified in the Inf_03. The failure modes observed in each of the tests reveals different out-of-plane behaviour of the IM walls with and without previous in-plane damages. The tests in original IM walls (Inf_01 and Inf_02) showed vertical cracking, with detachment between the infill panel and the surrounding RC frame in the top and bottom joints. In the Inf_02 wall a trilinear cracking was observed with concentrated deformation in the middle point of the wall, with slight cracking in the top joint. For the test with previous in-plane damage only the detachment was observed between the infill panel and the surrounding top beam and columns, and typical rigid body behaviour was found.

Additionally it was presented a presents a simplified macro-model to simulate the IP and OOP behaviour of IM walls when subjected to seismic loadings. This model is adapted from the typical bi-diagonal strut model, which considers the non-linear behaviour of the infill panel and its contribution to the global response of the RC frames. The OOP behaviour is introduced through the location of the infill mass in two central nodes of the bi-diagonal struts. An OOP elastic behaviour was considered for the numerical model as well as in-plane and out-ofplane interaction. This interaction mechanism allows considering IM collapse if the IP and/or 
OOP is reached. Further investigations should be performed to define IP and OOP drift limits according to different types of IM units, with the main goal of approximate the IM wall numerical and response of the IM behaviour subjected to seismic loadings during the last years. Following a brief presentation of the macro-model, three RC buildings with the same geometric and mechanical properties were numerically modelled and subjected to non-linear static time-history analysis for three different situations: bare frame; with infills considering only IP behaviour and with infills considering IP and OOP behaviour. It was observed that the consideration of the OOP infills' behaviour increased the vulnerability of the building, leading to the collapse of the most vulnerable storeys for peak ground accelerations above $0.3 \mathrm{~g}$. A significant difference was observed between the IP and IP_OOP numerical models, which points out to the need of considering the OP behaviour of the IM walls for proper seismic safety assessment of existing RC infilled structures.

\section{ACKNOWLEDGMENTS}

This experimental research was developed under financial support provided by "FCT Fundação para a Ciência e Tecnologia", Portugal, namely through the research project P0CI01-0145-FEDER-016898 - Safety Evaluation and Retrofitting of Infill masonry enclosure Walls for Seismic demands. The authors would like to acknowledge the technicians of the Laboratory of Earthquake and Structural Engineering (LESE), Mr. Valdemar Luis and Mr. Nuno Pinto for their support in the experimental activity reported in this paper, and Preceram for the provision of all the bricks used in the experimental tests.

\section{REFERENCES}

[1] R. Vicente, H. Rodrigues, H. Varum, A. Costa, and R. Mendes da Silva, "Performance of masonry enclosure walls: lessons learned from recent earthquakes," Earthquake Engineering and Engineering Vibration, vol. 11, pp. 23-34, 2012.

[2] Eurocode 6: Part 1-1 - General Rules for buildings - Rules for reinforced and unreinforced masonry, European Committee for Standardisation, Brussels, 2005.

[3] Eurocode 8: Design of structures for earthquake resistance - Part 1-1: General rules, seismic actions and rules for buildings, B. European Committee for Standardization, Belgium, 2003.

[4] X. Romão, A.A.Costa, E. Paupério, H. Rodrigues, R. Vicente, H. Varum, et al., "Field observations and interpretation of the structural performance of constructions after the 11 May 2011Lorca earthquake," Eng. Fail. Anal. , vol. 34, pp. 670-692, 2013.

[5] G. Brando, D. Rapone, E. Spacone, A. Barbosa, M. Olsen, D. Gillins, et al., "Reconnaissance report on the 2015 Ghorka earthquake effects in Nepal," in Anidis 2015 - XVI Conference, L'Aquila, Italy, 2015.

[6] H. Varum, A. Barbosa, A. Arêde, N. Vila-Pouca, H. Rodrigues, A. Furtado, et al., "April 2015 Ghorka earthquake in Nepal: field observations," presented at the $10^{\circ}$ Concregsso Nacional de Sismologia e Engenharia Sísmica, Azores (Portugal), 2016.

[7] NBC 205, "Mandatory Rules of Thumb Reinforced Concrete Buildings Without Masonry Infill," Nepal National Building Code, HMG/Ministry of Housing and Physical Planning, Department of Building, Kathmandu, Nepal, 1994.

[8] "NBC 105, "Seismic Design of Buildings in Nepal," Nepal National Building Code, HMG/Ministry of Housing and Physical Planning, Department of Building, Kathmandu, Nepal, 1994.."

[9] NI, "National Instruments - LabView software," ed, 2012. 
[10] A. Furtado, C. Costa, A. Arêde, and H. Rodrigues, "Geometric characterisation of Portuguese RC buildings with masonry infill walls," European Journal of Environmental and Civil Engineering, vol. 20, pp. 396-411, 20/04/2016 2016.

[11] F. Mckenna, G. Fenves, M. Scott, and B. Jeremic, "Open System for Earthquake Engineering Simulation (OpenSees)," ed. Berkley, CA, 2000.

[12] H. Rodrigues, H. Varum, and A. Costa, "Simplified Macro-Model for Infill Masonry Panels " Journal of Earthquake Engineering, vol. 14, pp. 390 - 416, 2010.

[13] A. Furtado, H. Rodrigues, and A. Arêde, "Modelling of masonry infill walls participation in the seismic behaviour of RC buildings using OpenSees," International Journal of Advanced Structural Engineering (IJASE), 2015.

[14] S. Kadysiewske and K. Mosalam, "Modeling of unreinforced masonry infill walls considering in-plane and out-of-plane interaction," Pacific Earthquake Engineering Research Center2009.

[15] A. Furtado, H. Rodrigues, A. Arêde, and H. Varum, "Simplified macro-model for infill masonry walls considering the out-of-plane behaviour," Earthquake Engineering \& Structural Dynamics, vol. 45, pp. 507-524, 2016.

[16] FEMA356, "Prestandard and commentary for the seismic rehabilitation of buildings," ed: Federal Emergency Management Agency, Washington(DC), 2000.

[17] Seismic Rehabilitation of Existing Buildings (ASCE/SEI 41-06), 2007.

[18] K. Mosalam and S. Gunay, "Progressive collapse analysis of RC frames with URM infill walls considering in-plane/out-of-plane interaction " Earthquake Spectra (In Press), 2014.

[19] S. Hak, P. Morandi, and G. Magenes, "Out-of-plane experimental response of strong masonry infills," presented at the Second European Conference on Earthquake Engineering and Seismology, Istanbull, 2014.

[20] E. Carvalho and E. Coelho, Análise Sísmica de estruturas de edifícios segundo a nova regulamentação - Análise Estrutural de um conjunto de 22 edifícios vol. II. Lisboa, Portugal, 1984.

[21] FEMA274, "NEHRP commentary on the guidelines for the seismic rehabilitation of buildings. FEMA-274, Applied Technology Council, Washington, USA.," ed: Federal Emergency Management Agency, Washington (DC), 1997.

[22] NTC08, "Decreto ministeriale 14 gennaio 2008 - Norme Tecniche per le Costruzioni NTC2008. Supplemento ordinario n. 30 Gazzetta Ufficiale 4 febbraio 2008, n 29. (in Italian)." 2008.

[23] FEMA306, "Evaluation of earthquake damaged concrete and masonry wall buildings: basic procedures manual. FEMA-306 - Applied Technology Council, Washington, USA.," 1998.

[24] FEMA273, "NEHRP guidelines for the seismic rehabilitation of buildings; FEMA 274, Commentary," ed: Federal Emergency Management Agency, Washington (DC), 1996. 